\title{
Analysis of crypt cell proliferation in coeliac disease using MI-B1 antibody shows an increase in growth fraction
}

\author{
R Przemioslo, N A Wright, G Elia, P J Ciclitira
}

\begin{abstract}
This study aimed to investigate the pattern of cellular proliferation and to calculate the growth fraction of small intestinal crypts in 24 patients - eight with untreated coeliac disease (CD), six with treated $C D$, and 10 controls with normal villous architecture. Duodenal biopsy specimens were stained with MI-B1 antibody using an immunoperoxidase method. Positive stained crypt cells were counted and their position within each intact crypt column was noted. These were used to construct proliferation index distribution curves for each cell position from which the crypt growth fraction for each group of patients was calculated. The crypt growth fraction was found to be higher in the untreated CD group (0.57) than in the treated patients $(0.39)$ and the controls $(0.44)$. The mean (SEM) proliferative index for each crypt was significantly higher in the untreated group $(42.3$ $(10.8) \% ; p<0.05)$ than in the treated CD $(21.7(8.5) \%)$ and control $(19.7(7.5) \%)$ groups and correlated closely with the surface:volume index and enterocyte cell height measurements in all three groups. An increased growth fraction may contribute to other changes in crypt cell kinetics to produce the histological changes seen in untreated CD.

(Gut 1995; 36: 22-27)
\end{abstract}

Keywords: coeliac disease, immunohistochemistry, crypt cell proliferation.

Gastroenterology Unit (UMDS), St Thomas's Hospital, London R Przemioslo P J Ciclitira

Imperial Cancer Research Foundation, Lincoln's Inn Fields, London

N A Wright

G Elia

Correspondence to: Correspondence to:
Professor P J Ciclitira, Gastroenterology Unit, St Thomas's Hospital, London SE1 7EH.

London SE1 7EH. 21 April 1994 their normal columnar appearance and become cuboidal. ${ }^{2}$ It has been proposed that these histological appearances are caused by changes in the mucosal immune microenvironment created by the secretion of abnormal amounts of biologically active
Coeliac disease (CD) is an inflammatory small drawal of dietary gluten. There is an increased including small bowel carcinoma, with and in those patients is greater in men with to treatment with a gluten free diet. ${ }^{1}$ The histological appearance in untreated CD is of an avillous mucosa together with elongation mediators from cells involved in the cell mediated response to gluten. These may affect crypt cell proliferation and epithelial cell toxicity by different pathways.

The monoclonal antibody MI-B1 was developed in the Institute of Pathology, Kiel University, Germany. ${ }^{3}$ It is a murine IgG antibody which recognises a nuclear antigen consisting of $395 \mathrm{kDa}$ and $345 \mathrm{kDa}$ parts. Staining with MI-B1 increases through the cell cycle from $G 1$ to $G 2$ but sharply reduces after mitosis and is totally absent in Go. It has been shown by western blotting that MI-B1 recognises the same antigen as $\mathrm{Ki}-67$ and therefore stains cells in all parts of the cell cycle. ${ }^{4}$ Previously, Ki-67 work was only possible on frozen sections as the epitope which the antibody recognises is concealed by tissue fixation. MI-B1 recognises the $\mathrm{Ki}-67$ antigen equally well in microwaved formalin fixed and wax embedded sections as in frozen sections. ${ }^{56}$ The advantage of using MI-B1 is that it allows the study of archive material with better preservation of morphology within the tissues studied allowing a more accurate assessment of parameters such as the enterocyte cell height and surface:volume index $(\mathrm{S}: \mathrm{V})$ which are indicators of toxicity in coeliac disease mucosa. ${ }^{7}$

Within the small bowel, crypt cell division is thought to originate from pluirpotent stem cells which are located in the basal portion ${ }^{8}$ passing through the middle or proliferative zone of the crypt and emerging near the mouth of the crypt as functional non-proliferating cells. With the onset of the inflammatory process, it has been suggested that the proliferative compartment may expand to occupy a larger part of the crypt, however, previous attempts at estimating crypt growth fraction by identifying cells in mitosis showed a reduction of the growth fraction in untreated CD crypts.

Our aim was to study the change in the crypt growth fraction in coeliac disease mucosa, to see how this varies on treatment with a gluten free diet, and the relation between total crypt cell labelling index and other known markers of toxicity in this disease. Taken together with other data on crypt cell kinetics, the results will help us to understand the mechanisms by which the characteristic mucosal lesion develops. The results may be of help as a baseline study for investigating the role of individual cytokines and growth factors in causing this lesion. An estimate of growth fraction using MI-B1 


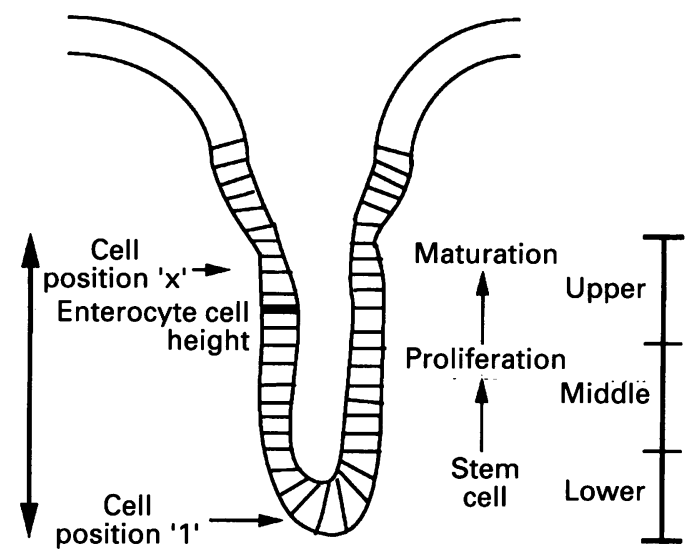

Muscularis mucosa

Figure 1: Method of sequential counting of cells within a crypt. Cells were counted in the left column of longitudinally cut crypts from the base which was designated cell position ' 1 ' upwards to the mouth of the crypt. The number of cells counted along this length was divided into thirds which approximated to the lower (stem cell), middle (proliferative) and upper (maturation) compartments. Enterocyte cell height was taken as a linear measurement from the basement membrane to the surface of the cell as shown.

provides new information as this will identify all cells in the cell cycle rather than only those in mitosis, as in previous studies.

\section{Methods}

\section{PATIENT POPULATION}

\section{Untreated coeliac disease}

Eight patients (five men and three women, mean age 43.5 years, range $22-67$ years) with histological evidence of coeliac disease from small bowel biopsies which improved subsequently after six months treatment with a gluten free diet according to the modified ESPGAN criteria for diagnosis. ${ }^{9}$

\section{Treated coeliac disease}

Six patients (three men and three women, mean age 46.2 years, range 37-61 years) previously diagnosed with coeliac disease (as above) who had been treated with a gluten free diet for at least six months (mean 11.3 months, range 7.4-26.6 months) with resolution of small intestinal villous architecture.

\section{Control patients}

Ten patients (seven men and three women, mean age $37 \cdot 0$ years, range $19-66$ years) with morphologically normal small bowel biopsy specimens found in the course of routine diagnostic investigations and who were all eventually found to be suffering from the irritable bowel syndrome.

\section{BIOPSY SPECIMENS}

Biopsy specimens were obtained endoscopically from the distal duodenum, orientated, and placed in formalin fixative before being embedded in paraffin wax. Sections were cut at $5 \mu \mathrm{m}$ thickness on a Leitz Microtome.

\section{PRETREATMENT OF SLIDES}

Slides were microwaved before staining as described elsewhere. ${ }^{10}$ Briefly, slides were placed in pre-warmed $0.01 \mathrm{M}$ tri-sodium citrate solution $(\mathrm{pH} 6.0)$ in a glass rack in a microwave proof container, then microwaved at $700 \mathrm{~W}$ for 20 minutes, in two lots of 10 minutes with replenishment of the buffer in between. The length of time required for microwaving was titrated, since this varies according to the antigenic epitope and tissue studied. After microwaving, the slides were taken out of sodium citrate solution and placed directly in warm phosphate buffered saline (PBS) before immunostaining.

\section{STAINING OF SLIDES}

The primary layer murine monoclonal antibody MI-B1 (The Binding Site, UK) was applied at 1:100 dilution for 35 minutes. The second layer antibody used was rabbit antimouse (Dako E354) at 1:300 dilution for 30 minutes and detection was with streptavidinperoxidase (Dako 397) at 1:500 dilution for 30 minutes finishing by incubating with $\mathrm{DAB}$ for two to three minutes. Sections were washed thoroughly with PBS in between each of the above steps.

\section{ASSESSMENT OF SLIDES}

Analysis of staining with MI-B1 antibody

Positively stained cells were counted and expressed as a percentage of the total cells within each vertical crypt cell column and this represented the crypt proliferation index. Enough sections were cut to allow us to analyse at least five (range 5-13, mean 8.6) distinct crypts per patient, and so at least 30 per patient group. Crypts were cut along their longitudinal axis and cells were counted along the left hand side of the column of crypt cells from the base to the mouth of the crypt. Positive cells were easily differentiated from negative cells, and staining was uniform throughout sections. Counts were also assessed blindly by a second observer and the results obtained were correlated. Crypt length was measured as the number of cell units along the left hand column of cells in the crypt, and their position within each crypt length was noted taking the cell at the base of the crypt as position ' 1 ''1 (see Fig 1). Results were expressed with reference to each third of the crypt having divided the total number of cells counted per crypt by three, each third then representing the upper (mouth), middle, and lower (basal) portion (see Fig 1).

\section{Calculation of the crypt growth fraction for each} patient group

The definition of growth fraction is a proportion of cells which are engaged in the cell 
TABLE I Morphometric and growth fraction analysis of the three patient groups

\begin{tabular}{llll}
\hline & Untreated CD & Treated CD & Controls \\
\hline Crypt depth (no of cells) & $82(8 \cdot 3)^{\star} \dagger$ & $62(8 \cdot 2)$ & $50(9 \cdot 8)$ \\
Half maximum point (cell pos) & 47 & 24 & 22 \\
Growth fraction & $0 \cdot 57$ & $0 \cdot 39$ & $0 \cdot 44$ \\
S:V index & $13 \cdot 9(0 \cdot 8)^{\star} \dagger$ & $38 \cdot 4(2 \cdot 8)^{\star}$ & $50 \cdot 9(6 \cdot 7)$ \\
Enterocyte cell height $(\mu \mathrm{m})$ & $14 \cdot 6(3 \cdot 7)^{\star} \dagger$ & $24 \cdot 7(5 \cdot 7)$ & $25 \cdot 7(7 \cdot 2)$
\end{tabular}

$\star$ Denotes $p<0.05$ compared with the control group, tdenotes $p<0.05$ compared with the treated CD group, the numbers in brackets represent the standard error of the mean. $\mathrm{CD}=$ coeliac disease; $\mathrm{S}: \mathrm{V}$ index $=$ surface area:volume index.

cycle which, if all cells in the proliferative compartment are cycling, is equivalent to the relative size of the proliferative compartment. Within the crypt column, we calculated the percentage of positively stained crypt cells at each cell position pooled from all patients within each group. This constitutes the proliferative index at that position. Each of these values was then used to construct proliferation index distribution curves for crypts with a length equal to the mean of the appropriate group. The values increase from basal cell positions to a maximum in the proliferative compartment of the crypt and then diminish as the cells leave the cell cycle and enter the maturation compartment at a point called the decycling zone. The growth fraction can be calculated using the theoretical slow cut off model proposed by Cairnie, Lamerton, and Steel, which proposes an increasing probability of a decycling division occurring over a particular portion of the crypt. This point approximates to the cell position at which the proliferation index falls to half of the maximum value (half maximum position) on the trailing edge of the curve and then divided by the mean crypt height. ${ }^{12-14}$

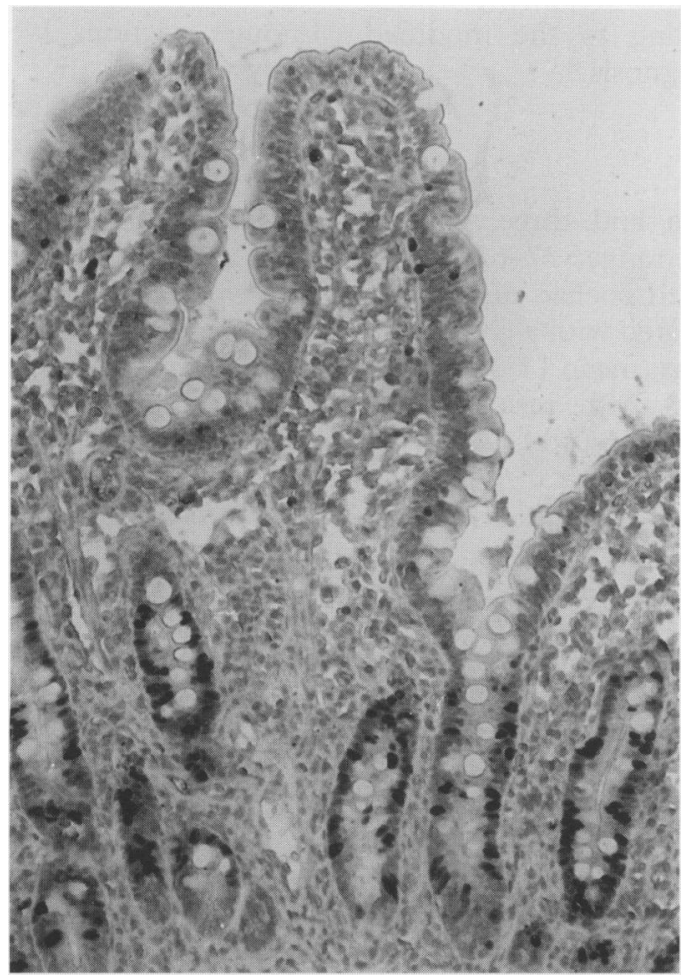

Figure 2: The normal pattern of staining seen in small intestinal tissue (original magnification $\times 250$ ).

\section{Morphometric analysis}

Enterocyte cell height was estimated by counting cells at approximately one third of the length from the top of a villus using a Leitz microscope with a calibrated eyepiece at $\times 125$ magnification. ${ }^{15}$ At least three villi and 10 cells per villus were counted randomly and the mean height calculated in micrometres $(\mu \mathrm{m})$. Enterocytes were counted throughout each section but not selected from crypts, tips of villi, or areas of obvious morphological distortion (see Fig 1).

\section{Stereological measurement}

An estimate of villous flattening was made using stereological analysis with a Weibel graticule (Graticules Ltd, Tunbridge Wells, Kent) fitted into a Leitz Westlar microscope eyepiece and counting done at a constant $\times 125$ magnification. ${ }^{16}$ The number of times lines on the graticule cut the mucosal surface, termed 'cuts' (c) and the number of times the endpoints of the line fell within the covering epithelium and muscularis mucosa, termed 'hits' (h) were noted for each patient. Enough sections were analysed for each patient so that at least 200 'hits' (h) were counted. The length of each line of the graticule at this magnification (1) was found to be $1.7 \times 10^{-2} \mathrm{~cm}$ and the ratio of c/lh calculated. This can be regarded as a measure of small intestinal surface area to volume index $(\mathrm{S}: \mathrm{V})$. Previous work has shown that sterology is an accurate method of determining changes in villous flattening. ${ }^{17}$

CONTROLS

Sections from human tonsil served as a positive control. Omission of the primary incubating antibody as a negative control.

\section{STATISTICS}

Statistical analysis of differences between groups was done using the Student's unpaired $t$ test. Analysis of the correlation between variables was performed by Spearman signed rank correlation. Differences were considered significant if a $p$ value of less than $5 \%$ was obtained.

\section{Results}

The results show a significant increase in the duodenal crypt length by counting the number of cells per intact crypt length in untreated coeliac disease when compared with patients with treated coeliac disease and normal controls $(\mathrm{p}<0.05$ each). There was a significant reduction in the surface to volume index $(\mathrm{S}: \mathrm{V})$ and a significant reduction in the enterocyte cell height in the untreated CD group $(p<0.05$ each) compared with the other two groups. There was no significant difference in any of these parameters between the treated $\mathrm{CD}$ and control groups except for the $\mathrm{S}: \mathrm{V}$ index which was just significantly less in the treated CD group ( $p=0.049$ ) (see Table I). 


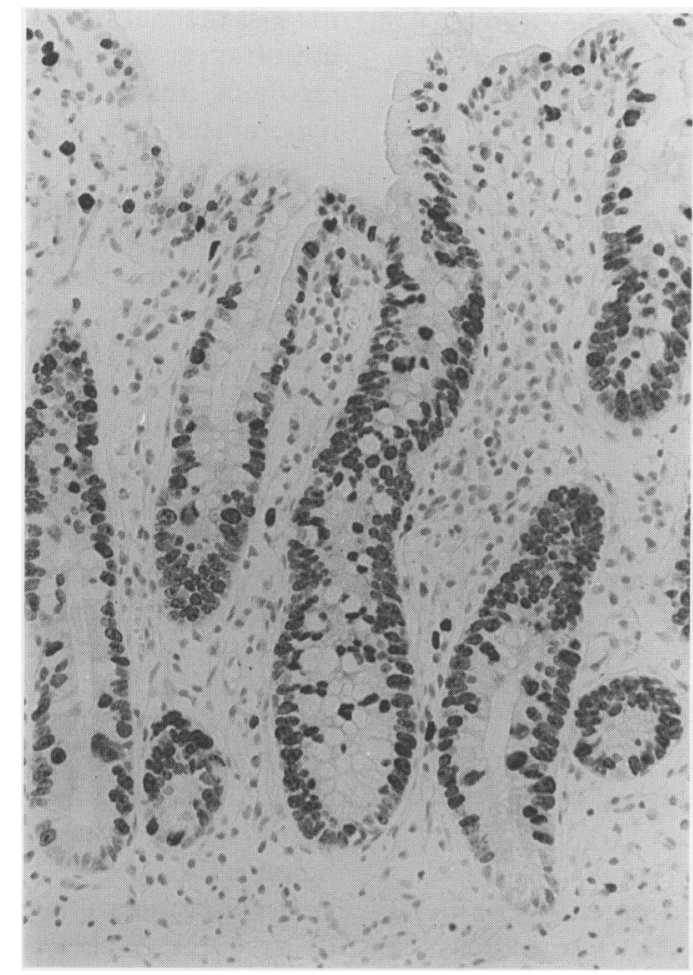

Figure 3: An elongated crypt in a patient with untreated coeliac disease. The dark staining (positive) cells extend throughout its length, appearing higher up the crypt than in normal uninflamed tissue (original magnification $\times 250$ ).

Staining with the monoclonal antibody MI-B1 produced a clearly visible brown coloration of crypt cells in cycle which was subjectively greater in the untreated CD group than the other two groups. This staining pattern obtained was evenly distributed throughout each section. Slides were coded and assessed blindly by a second observer and

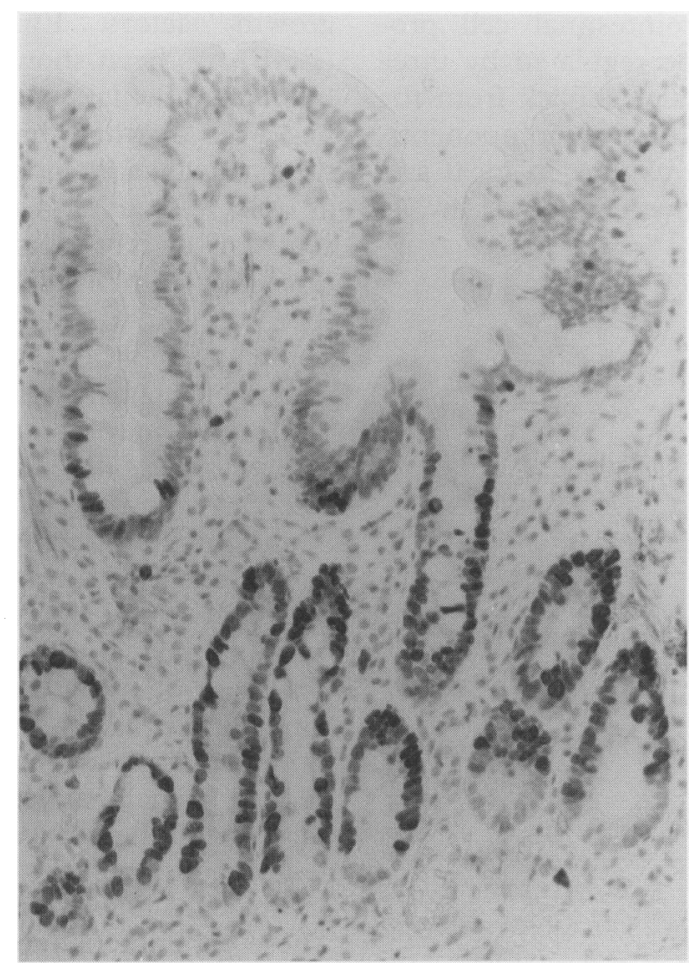

Figure 4: Small bowel biopsy tissue from a patient with coeliac disease treated with a gluten free diet showing a near normal pattern of staining with MI-B1 (original magnification $\times 250$ ).
TABLE II The \% proliferation index in each third of the crypts as detected by staining with MI-B1 (values mean (SEM))

\begin{tabular}{lllr}
\hline & Untreated CD & Treated CD & \multicolumn{1}{c}{ Controls } \\
\hline Upper & $18 \cdot 8(9 \cdot 3)^{\star} \dagger$ & $4 \cdot 5(3 \cdot 3)$ & $3 \cdot 5(3 \cdot 0)$ \\
Middle & $66.5(8 \cdot 4)^{\star}+$ & $37 \cdot 4(10 \cdot 6)$ & $32 \cdot 5(8 \cdot 1)$ \\
Lower & $41.5(12 \cdot 4)^{\star} \dagger$ & $23 \cdot 1(11 \cdot 1)$ & $23 \cdot 0(9 \cdot 9)$ \\
Total & $42.3(10 \cdot 8)^{\star} \dagger$ & $21 \cdot 7(8 \cdot 5)$ & $19 \cdot 7(7 \cdot 5)$ \\
\hline
\end{tabular}

^Denotes $\mathrm{p}<0.05$ compared with the control group, tdenotes $p<0.05$ compared with treated CD group.

$\mathrm{CD}=$ coeliac disease.

the results obtained by each of them correlated closely (Spearman statistic, $0.92 ; \mathrm{p}=0.003$ ). Using our staining method and length of microwaving specific for gut antigen exposure, little background staining of lymphocytes was found (see Figs 2-4).

The mean percentage of crypt cells which stained positive with the monoclonal antibody MI-B1 was increased not only in the whole of the crypt (see Table II) but significantly raised in the upper, middle, and lower thirds of the crypts when these were divided equally after counting of crypt cells sequentially, thus suggesting the presence of an expanded number of cells in division (Fig 5). This was considered in detail when the size of the proliferative compartment was calculated for each patient group by constructing proliferation index distribution curves (see Fig 6). From these curves the half maximum point was found to be doubled in the untreated CD group (cell position 47) compared with the treated (cell position 24) and control groups (cell position 22). This reflected an increase in growth fraction in the untreated CD group $(47 / 82,0.57)$ compared with treated CD $(24 / 62,0.39)$ and control $(22 / 50,0.44)$ groups.

Importantly there was little difference in any of the proliferation data obtained for the treated $\mathrm{CD}$ and control groups.

The increase in individual crypt labelling index correlated very closely with the other known indices of toxicity in CD, namely a reduction in enterocyte cell height and surface area to volume index (Fig 7).

\section{Discussion}

Our findings show that the proliferating crypt cell compartment in the untreated $C D$ group covered a greater portion of the expanded crypt. We have been able to quantify this proliferative response using MI-B1. Changes in the crypt proliferation index detected by MI-B1 correlated with the known indices of toxicity in CD, enterocyte cell height and surface area to volume index with crypt proliferation index.

An important observation is that we found an increase in the growth fraction of small intestinal crypts in the untreated coeliac disease group. Previous work involved only the counting of crypt cell mitotic figures and suggested that the growth fraction was decreased in untreated CD due to the massive increase in the total crypt cell population over and above that of crypt cells in the ' $M$ ' phase of the cell cycle. ${ }^{18}$ Our results may have differed because 


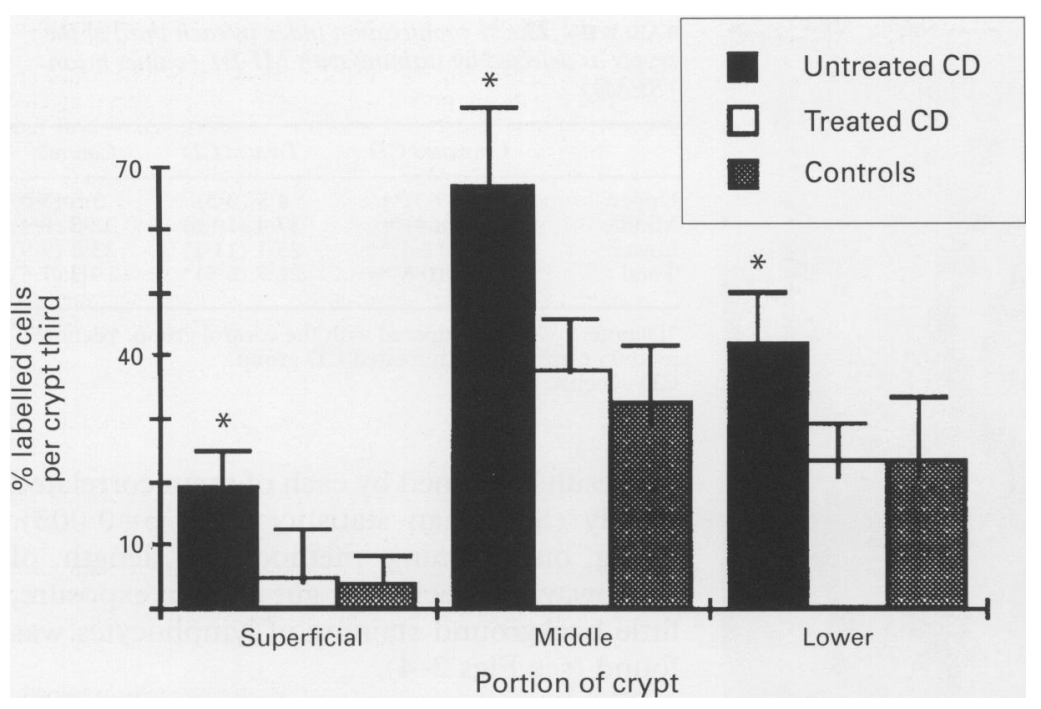

Figure 5: Crypt labelling index per portion of crypt in the three patient groups. There was a significant increase in crypt cell labelling with MI-B1 in all three portions of the crypt in untreated coeliac disease (CD) compared with the treated $C D$ and the control groups. Importantly there was no significant difference in the pattern of staining between the latter two groups. *Denotes $p<0.05$ compared with control.

the method we used recognised cells in all the stages of the cell cycle. The increase in growth fraction will contribute, together with a previously shown increase in the crypt cell migration rate and a halving of the cell cycle duration, to cause the massive elongation of crypts and apparent villous flattening which is seen in untreated CD. In normal tissue the proliferative compartment is present in the middle to lower third, as is also the case in treated CD patients, and it is that the altered immunological microenvironment which occurs in untreated $\mathrm{CD}$ results in the stimulation of normally quiescent cells higher up the crypt. The next task will be to determine what cellular events initiate these changes in cell kinetics.

The control of gastrointestinal cell proliferation is thought to be regulated by three main mechanisms, a local feedback from the functional to the reproductive components, luminal nutrition, and a change in local and systemic peptides and growth factors. ${ }^{19}$ In CD

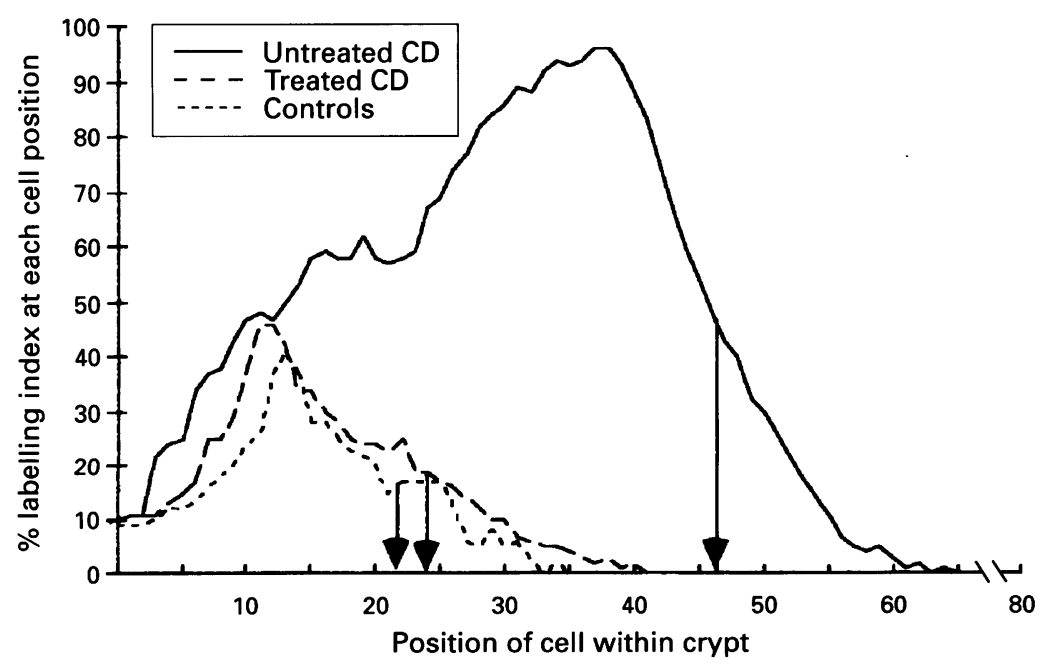

Figure 6: Proliferation index distribution curves for the three groups of patients. The distribution of the crypt cell labelling indices for each of the three patient groups are shown. The arrows correspond to the half maximum position for staining which then enables calculation of the growth fraction. the last mechanism is thought to be of greatest importance. Evidence obtained from studies involving gluten challenge indicate that crypt hyperplasia occurs at an earlier stage to any observed reduction in enterocyte cell height and that the theory implicating enterocyte shedding resulting in stimulation of crypt hyperplasia may not be valid in this disease. ${ }^{20}$ It has also been shown in an in vitro system that crypt cell hyperplasia and villous flattening can occur without a change in enterocyte cell height. ${ }^{21}$ However, there is little work which conclusively shows that any specific $\mathrm{T}$ cell released factor can cause an increase in crypt cell proliferation in vivo. Work with a fetal organ culture system has shown that stimulating small intestinal mucosal $\mathrm{T}$ cells with mitogens, and anti-CD3 in particular, caused crypt cell hyperproliferation and crypt hypertrophy together with apparent villus flattening but when the individual cytokines interleukin 2 (IL 2) and interferon $\gamma$ were added to the organ culture system these changes could not be reproduced. ${ }^{21}$

IL 6, a macrophage derived cytokine, and its receptor have recently been shown to be present in increased amounts in human intestinal epithelial cells in some diseases, especially in carcinoma. ${ }^{22}$ The increase in its production by intestinal epithelial cells is augmented by tumour necrosis factor $\alpha$, transforming growth factor $\beta$ (TGF $\beta$ ) and IL $1 \beta,{ }^{23}$ which are found in increased amounts in a number of inflammatory enteropathies. It has been shown that IL 6 can up- or down-regulate cell proliferation in a number of systems and that normal and neoplastic intestinal epithelial cells may be autocrinally regulated by it. ${ }^{24}$

Apart from cytokines, other peptides which have been shown to affect the intestinal epithelial cell proliferative response include growth factors. Epidermal growth factor (EGF) has been shown to be a potent stimulator of epithelial cell production in man, ${ }^{25}$ as has TGF $\alpha$, which has a similar but less pronounced effect by binding to the same receptor as EGF. ${ }^{26}$ TGF $\beta$, in addition to increasing the synthesis of IL 6 , has been shown to be produced by epithelial cells, which also express its receptor, and it may have a role in directly influencing epithelial cell turnover. ${ }^{27}$

The mechanism by which crypt proliferation is induced may involve subepithelial mesenchymal cells as they have been shown to have a role in maintaining normal epithelial cell proliferation and differentiation. ${ }^{28}$

The effects of growth factors and cytokines on small bowel crypt cell proliferation need further study, and this may be achieved by observing their effect on explanted human small intestinal biopsy material in organ culture. An important aim of this study was to document the change in the crypt proliferative pattern and then to assess the ability of growth factors and cytokines to induce these changes on normal small bowel mucosa grown in vitro. These experiments are currently being undertaken by a number of workers.

Hyperproliferation is considered part of the process in the development of carcinogenesis 

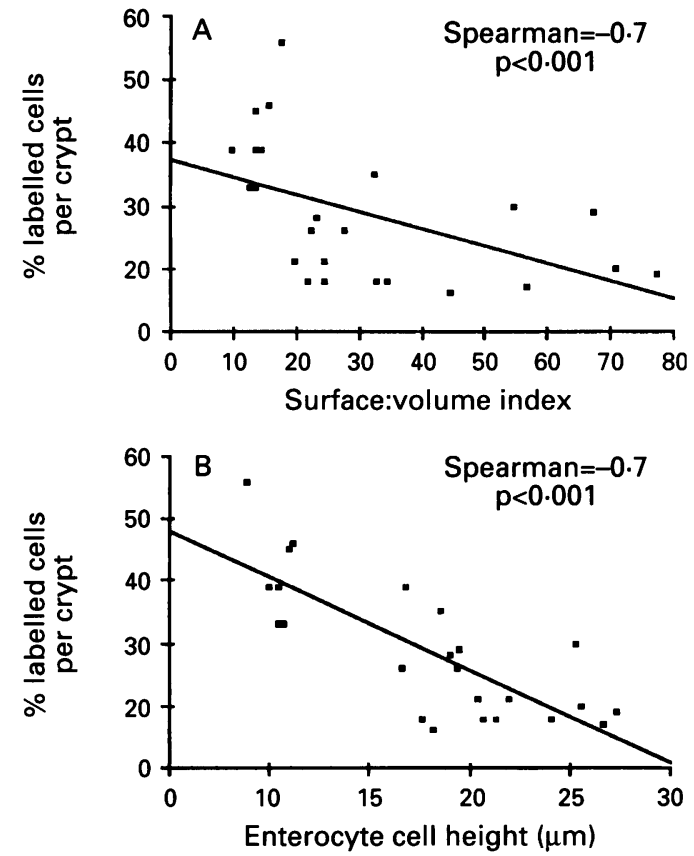

Figure 7: There were strong correlations between $(A)$ the total crypt labelling and a reduction in the surface: volume index and $(B)$ between total crypt labelling and a reduction in the enterocyte cell height.

in tissues. ${ }^{29}$ The high rates of proliferation may 'fix' damaged DNA before repair is possible. Most gastrointestinal tract tumours arise out of a focal area of dysplasia, a first manifestation of which is a loss of differentiation and an upwards expansion of the proliferative zone such as we found in our untreated $C D$ patients. ${ }^{30}$ The picture seen in untreated $C D$ resembles superficially the pattern of proliferation seen in neoplastic epithelium, with the loss of focal areas of regenerative cells and a more expanded uniform population of cells in division. ${ }^{31}$ This may be of relevance in a disease in which the incidence of small bowel carcinoma is increased. In ulcerative colitis, studies have shown a failure of the pattern of proliferation to return to normal after remission. ${ }^{32}$ However, we found the pattern of proliferation in treated $C D$ to be nearly identical to that in normal tissue. It would be interesting to assess whether this varies with the length of time on a gluten free diet, especially in those at greatest theoretical risk - that is, male or those in whom dietary compliance is poor. It would also be interesting to study archive material from patients with small intestinal cancers to see whether the pattern of proliferation had been more diffuse before the development of cancer when on a gluten free diet.

This work was presented in part as a paper at the British Society of Gastroenterology meeting in Warwick, September 1993. of Gastroenterology meeting in Warwick, September 1993 . RP acknowledges financial support from
Hospital Research (endowment) Committee.

1 Holmes G, Prior P, Lane M, Pope D, Allan R. Malignancy in coeliac disease-effect of a gluten free diet. Gut 1989; 30: 333-8.

2 Katz A, Falchuk Z. Definitive diagnosis of gluten-sensitive enteropathy Gastroenterology 1978; 75: 695-700.

3 Cateropathy. Gastroenterology 1978 , 75: 69 M, Schluter C Galle J, et al. Monoclonal antibodies against recombinant parts of the Ki67 antigen (MIB1 and MIB3) detect prolif- erating cells in microwave processed formalin-fixed paraffin sections. f Pathol 1992; 168 (4): 357-63.

4 Key G, Becker M, Baron B, Duchrow M, Schluter C, Flad $\mathrm{H}-\mathrm{D}$, et al. Preperation and (MIB1-3) generated against recombinant parts of the Ki67 antigen. Analytical Cell Pathology 1992; 4: 159.

5 Gerdes J, Becker M, Key G. Immunohistological detection of tumour growth fraction (Ki-67 antigen) in formalinfixed and routinely processed tissues. F Pathol 1992; 168: 85-6.

6 McCormick D, Chong H, Hobbs C, Datta C, Hall P. Detection of the Ki67 antigen in fixed and wax embedded sections with the monoclonal antibody MIB1. sections with the monoclo
Histopathology 1994 (in press)

7 Doniach I, Shiner M. Duodenal and jejunal biopsy histology. Gastroenterology 1957; 33i: 71-86.

8 Potten C, Hendry J. Stem cells in the small intestine. In: Potten C, ed. Stem cells. Edinburgh: ChurchillLivingstone, 1983: 155-99.

9 Walker-Smith J, Guandalini S, Schmitz J, Shmerling D, Visakorpi J. Revised criteria for diagnosis of coeliac disease. Arch Dis Child 1990; 65: 909-11.

10 Shi R, Key M, Kalra K. Antigen retrieval in formalin fixed paraffin embedded tissues an enhancement method for heating of tissue sections. F Histochem Cytochem 1991; 39: 741-8.

11 Kaur P, Potten C. Circadian variation in migration velocity in small intestinal epithelium. Cell Tissue Kinet 1986; 19: 591-9.

12 Watson A, Wright $\mathrm{N}$, Appleton D. In: Appleton D, Sunter J, Watson A, eds. Cell proliferation in the gastrointestinal tract. Tunbridge Wells: Pitman Medical, 1980: 350-63.

13 Cairnie A, Lamerton L, Steel G. Cell proliferation studies in the intestinal epithelium of the rat. I. Determination of the kinetic parameters. Exp Cell Res 1965; 39: 528-38.

14 Cairnie A, Lamerton L, Steel G. Cell proliferation studies in the intestinal epithelium of the rat, II. Theoretical aspects. Exp Cell Res 1965; 39: 539-53.

15 Stewart J, Pollock D, Hoffbrand A. A study of proximal and distal intestinal structure and absorptive function in idiopathic steatorrhoea. $Q \mathcal{F}$ Med 1967; 36: 425-44.

16 Dunnill $M$, Whitehead R. A method for the quantitation of small intestinal biopsy specimens. $\mathcal{F}$ Clin Pathol 1972; 25: 243-6.

17 Corazza G, Frazzoni M, Dixon M, Gasbarrini G. Quantitative assessment of the mucosal architecture of jejunal specimens: A comparison between linear measurement, stereolog and computer aided microscopy. m Clin Pathol 1985; 38: 765-70.

18 Wright N, Morley A, Appleton D, Marks J. Cell kinetics in flat avillous mucosa of the human small intestine. Gut 1973; 14: 701-10.

19 Wright $\mathbf{N}$, Alison $M$. In: Wright $N$, ed. The biology of epithelial cell populations. Vol 1. Oxford: Oxford University Press, 1984

20 Marsh M, Loft D, Garner V, Gordon D. The temporal/dose response of coeliac mucosa to graded oral challenges with Frazer's fraction III. European fournal of Gastroenterology and Hepatology 1992; 4: 667-73.

21 Ferreira R, Forsyth L, Richman P, Wells C, Spencer J, MacDonald T. Changes in the rate of crypt epithelial cell proliferation and mucosal morphology induced by a T-cell mediated response in human small intestine. Gastroenterology 1990; 98: 1255-63.

22 Shirota K, LeDuy L, Yuan SY, Jothy S. Interleukin 6 and its receptor are expressed in human intestinal epithelial cells. receptor are expressed in human intestinal
Virchows Archiv-B 1993; 58 (4): 303-8.

23 McGhee D, Beagley K, Aicher W, McGhee J. Transforming growth factor $\beta$ and interleukin $1 \beta$ act in synergy to enhance IL-6 secretion by the intestinal epithelial cell line IEC-6. F Immunol 1993; 151 (2): 970-8.

24 Kraeger J, Ray A, Tamm I, Sehgal P. Expression and function on interleukin 6 in epithelial cells. $\mathcal{f}$ Cell Biochem $1991 ; 45$ (4): 327-34

25 Carpenter G. Epidermal growth factor. In: Baserga R, ed. Tissue growth factors. Berlin: Springer-Verlag, 1981: 89-123.

26 Burgess A. Epidermal growth factor and transforming growth factor $\alpha . B$ Med Bull 1989; 45: 401-24.

27 Murthy U, Anzano M, Greig R. Expression of TGF $\alpha / E G F$ and TGF $\beta$ receptors in human colon carcinoma cell lines. Int $\mathcal{f}$ Cancer 1991; 44: 110-7.

28 Haffen K, Kedinger M, Simon-Assman P. Mesenchymedependent differentiation of epithelial progenitor cells in the gut. F Paediatr Gastroenterol Nutr 1987; 6: 14-23.

29 Ames B. Endogenous oxidative DNA damage, ageing and cancer. Free Radic Res Commun 1989; 7: 121-8.

30 Chang. W. Pathogenesis and biological behaviour of 1,2-dimethylhydrazine-induced colonic neoplasms in the proliferation in the gastrointestinal tract. London: Pitman proliferation in the gastrointestinal

$31 \mathrm{Lieb} \mathrm{L}$, Lisco $\mathrm{H}$. In vitro uptake of tritiated thymidine by carcinoma of the human colon. Gastroenterology 1966; 26 (4): 733-40.

32 Serafini E, Kirk A, Chambers T. Rate and pattern of epithelial cell proliferation in ulcerative colitis. Gut 1981; 22: 648-52. 